\title{
A STUDY OF MORPHOLOGICAL PATTERNS OF LIP PRINTS IN RELATION TO GENDER AND BLOOD GROUPS AMONG EGYPTIAN POPULATION
}

\author{
Dina A. Shokry*, Naglaa F. Mahmoud*, Mostafa M. Afify ${ }^{* *}$ \\ Department of Forensic Medicine and Clinical Toxicology, Faculty of Medicine, Cairo \\ University*, Beni Suef University**, Egypt
}

\begin{abstract}
Lip-print study (cheiloscopy) is a reliable biometric technology and considered as a unique parameter for identification. The aim of this study was to determine lip print patterns among sample of Egyptians population and evaluate their association with gender, ABO blood groups.A total of participants was 1000 (640 females \& 360 males) their ages ranged from (12 to 75 years), 15 identical twins and 34 families, were included in the study. Lip print was recorded by usage of Red or brown lip sticks, white copy papers and tissue paper, the obtained prints were first examined by magnifying hand lenses and later analyzed and interpreted. Blood groups were recorded from persons aware of their blood groups after reviewing of official documents if available. The results of this study revealed hat there was no identically similar lip-print pattern appeared in two subjects even $t$ among the same families and between identical twins. Groove type A (complete vertical) was the highest recorded pattern in both males $47.9 \%$ and females $49.7 \%$. It was predominantly observed in the lower middle area, followed by groove type $\mathrm{C}$ (complete bifurcation) which represented $43.8 \%$ (UL) area in males \& $45.4 \%$ (LR) area in females. The present Study proved that no correlation was found between lip print characteristics, blood groups and gender. In conclusion, lip prints are unique for every individual even in between the family and identical twins. Hence, Lip prints play a vital role as a supplementary tool in personal identification of suspects or unknown identity
\end{abstract}

Key words: lip prints, Cheiloscopy, Blood groups, gender, Identification

\section{INTRODUCTION}

Personal identification is an important and complex task in a medico-legal practice (Pradhuman et al., 2013). Dental, fingerprint and DNA matching are considered the most common techniques allowing rapid and secure personal identification. The public awareness of fingerprints is very high so usually there are intended attempts not to leave behind fingerprints at scene of the crime. This reason justifies the increasing need for reliable alternative methods of establishing identity The lip-print study (cheiloscopy) is considered a new technique for personal identification in both civil and criminal issues (Caldas et al., 2007).

Lips are two fleshy folds surrounding the oral orifice. They are covered externally by skin and internally by mucosa. The skin is continuous with the mucosa at the vermilion border, reddish zone lined by thin keratinized epithelium. Lip prints are unique patterns formed by wrinkles or grooves on the labial mucosa. Fischer in 1902 was the first anthropologist to describe the furrows 
on the red part of human lips (Kumar et al., 2012).

The importance of cheiloscopy is attributed to the fact that grooves of the lip prints occur as characteristic patterns and are peculiar to each individual (Thomas \&Van Wyk, 1988). Lip grooves are permanent and unchangeable like fingerprints and palatal rugae. Lip patterns are identifiable as early as the sixth week of intra uterine life and rarely change, resisting many conditions, such as herpetic lesions (Molano et al., 2002). Lip prints could be left at crime scenes on many objects e.g., cigarette butts drinking glasses, napkins, cakes, papers, duct tape (that used to tie a victim). Pattern study of the lip prints left at a scene of crime, and their comparison with those of the suspected individual may be useful for identification (Augustine et al., 2008).

Recently, there was an increasing acceptance of cheiloscopy in the legal community. Cheiloscopy workshops were conducted by the Federal Bureau of Investigation in the United States of America and in 1999, a U.S. court accepted the testimony of two state police experts that lip print identification is generally accepted within the forensic science community as a method of positive identification (Ball, 2002). The study of lip prints is not limited to visible prints left at a scene of crime. Latent or invisible prints can be developed and detected using aluminum powder and magnet powder (Sharma et al., 2009).

(Renaud, 1973), confirmed the singularity of lip print. He studied the lips in halves (left and right), and described the grooves according to their shape as 10 types (complete vertical, incomplete vertical, complete bifurcated, incomplete bifurcated, complete branched, incomplete branched, reticular, $\mathrm{X}$ or comma form, horizontal and the 10th type was specified for any other form). This classification was considered by (Caldas et al., 2007), as the most complete classification.

There are very few studies regarding the patterns and features of lip prints despite their prominent help as a useful evidence in human identification and crime solving. Correlating lip prints with blood groups has its importance in accurate identification of an individual than by using lip prints alone (Bushra \& Devanand, 2014).

The present study was conducted to study the distribution of different lip print patterns among large Egyptian sample at great Cairo and to ascertain whether there was a correlation between lip-print characteristics, blood groups and gender of the studied population.

\section{SUBJECTS \& METHODS 1 Subjects:}

A total of 1000 subjects (640 females \& 360 males) their ages ranged from (12 to 75 years) participated in this study. The study sample included 15 identical twins and 34 families. All subjects participated in the study were Egyptians residents at Great Cairo area. Lips with any evidence of inflammation, disease or injury were excluded. Blood groups were recorded from subjects aware of their blood groups. All the procedures for this study were approved by the ethical committee of forensic medicine and clinical toxicology department -faculty of medicine, Cairo University. Subjects were informed about the study and 
written consent was obtained from each participant.

\section{Method of Lip Print Recording:}

Red or brown, non-glossy, nonpersistent, non-metallic lip stick was used to obtain clear lip prints. White papers (white A4 ROCO Premium 80-g copy papers) and tissue papers (Kleenex) were used to get the impressions. Each participant was asked to clean the lip properly.A thin film of lipstick was applied onto the cleaned and dried lips, the subjects were asked to rub both lips to spread the applied lipstick uniformly, left for 3 min, and then the impressions of the lips were taken on the specified papers by applying direct light pressure by both lips on a folded paper (Aggrawal, 2004). At least 4 prints were taken from each participant to be sure that we had at least one complete, well defined print for proper examination of various areas of the lip, and to avoid subjective different pressure applied to the used paper.

\section{Analysis of the Lip Print:}

The lip print was divided into six topographic areas (each lip was divided into three areas) and each area was studied alone to determine the type of the grooves. A transverse line between the two highest points of the philtrum angles was drawn, and then two perpendicular lines were drawn on that transverse line. The perpendicular lines were extended to cut the upper and lower lips. Therefore, each lip print was divided into the following six areas: upper right (UR), upper middle (UM), upper left (UL), lower right (LR), lower middle (LM) and lower left (LL) as shown in Fig. 1 (Renaud, 1973 \& Renaud, 2007).

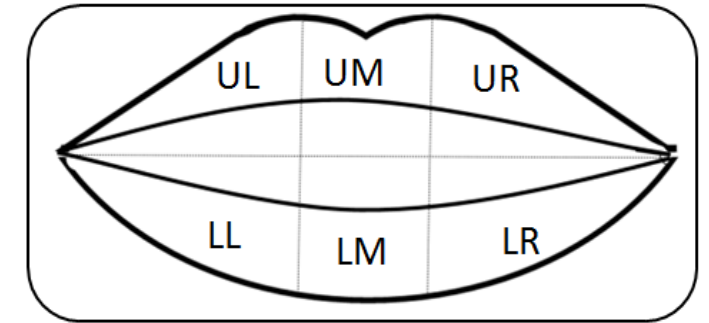

Figure (1): A diagram showing the compartmental areas of the lip. upper right (UR), upper middle (UM), upper left (UL), lower right (LR), lower middle (LM) and lower left (LL)

The lip prints were analyzed based on the classification of (Renaud, 2007), into 10 types, Therefore, the used classification was as follows: $\mathrm{A}=$ complete vertical, $\mathrm{B}=$ incomplete vertical, $\mathrm{C}=$ complete bifurcated, $\mathrm{D}=$ incomplete bifurcated, $\mathrm{E}=$ complete branched, F = incomplete branched, $\mathrm{G}$ = reticular pattern, $\mathrm{H}=\mathrm{X}$ or comma form, $\mathrm{I}=$ horizontal, $\mathrm{J}=$ other forms (curved, triangular, pentagonal or hexagonal arrangement) as shown in Fig. 2

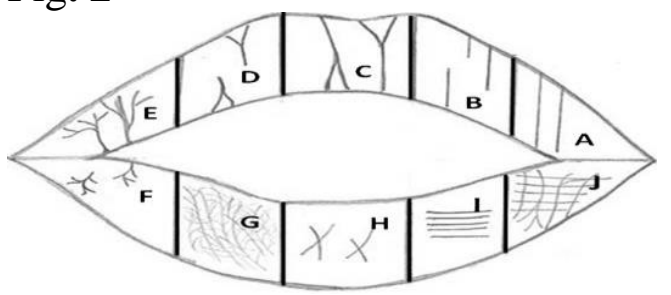

Figure (2): A diagram showing the lip groove types $\mathrm{A}=$ complete vertical, $\mathrm{B}=$ incomplete vertical, $\mathrm{C}=$ complete bifurcated, $\mathrm{D}=$ incomplete bifurcated, $\mathrm{E}=$ complete branched, $\mathrm{F}=$ incomplete branched, $\mathrm{G}=$ reticular pattern, $\mathrm{H}=$ $\mathrm{X}$ or comma form, $\mathrm{I}=$ horizontal, $\mathrm{J}$ : others forms.

The most lateral part of the lip print (near the angles of the mouth) was excluded as it was usually wrinkled. This study does not differentiate 
between (upward and downward) direction of the bifurcation. Each area was examined separately to detect the characteristic pattern of the grooves and the type which was repeated in maximum number of times, was considered as lip print type (Rajendran \& Sivapathasundram, 2009).

The obtained prints were first examined by magnifying hand lenses (with direct light focused on it) to choose the best clear complete print where the groove types could be analyzed. Only the best complete print of each participant was photographed by a digital camera (Nikon 300 D 12.5 MP) and examined by the picture manager programs to determine the Predominant Groove type in the examined areas.

The groove types of each print were recorded and kept in a specific folder to be examined for the individuality. Data were statistically analyzed to ensure the individuality of the lip print, first, we choose the highest recorded type then we analyzed other types in the rest of the examined areas. The prints that exhibited the same groove type in the same area were further differentiated by the types of grooves in other areas and so on. The prints that showed the same groove types in all areas of the print were reanalyzed by the program to ensure their difference in the site, length, and/or the pattern of branching of the groove.

\section{Statistical analysis:}

Data were coded and analyzed using the statistical package SPSS (Statistical Package for the Social Science) version 23. Data was summarized using frequency (count) and relative frequency (percentage) for categorical data. For comparing categorical data, Chi square $(\chi 2)$ test was performed. Exact test was used instead when the expected frequency is less than 5. P-values less than 0.05 were considered as statistically significant. Comparison between two groups was performed using t-test and $\mathrm{p}$ value was considered statistically significant if $\leq \mathbf{0 . 0 5}$ (Chan, 2003).

\section{RESULTS}

A total of 1000 subjects (640 females \&360 males) with age range of (12 - 75 years) participated in this study. The study included 15 identical twins and 34 families. Throughout the whole study there was no identically similar lip-print pattern appeared in two subjects. However, many subject showed the same groove types in the same areas of the lip but specificity of groove pattern was evidently present in either the site or the direction of branching or reticulation of the groove as shown in figure(3).

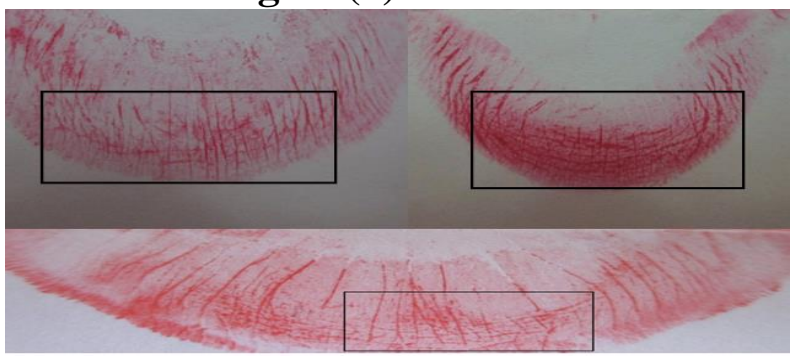

Figure (3): Photographs of lower lip prints of three Egyptian individuals having the same groove type (reticular pattern) in the lower middle area but with different patterns of reticulation.

As shown in table (1) there were $34.0 \%$ of lip prints exhibited the same pattern in LR and LL areas where, $36.4 \%$ of females and $29.7 \%$ of males with a significant difference. 
Table (1): Distribution of lip pattern similarities in different lip areas in relation to sex.

\begin{tabular}{|c|c|c|c|c|c|c|c|}
\hline Areas & \multicolumn{2}{|c|}{ Total } & \multicolumn{2}{c|}{ Female } & \multicolumn{2}{c|}{ Male } & \multirow{2}{*}{ P value } \\
\cline { 2 - 7 } & Count & $\%$ & Count & $\%$ & Count & $\%$ & \\
\hline $\begin{array}{c}\text { UR and UL areas } \\
\text { similiarites }\end{array}$ & 252 & $25.2 \%$ & 167 & $26.1 \%$ & 85 & $23.6 \%$ & 0.385 \\
\hline $\begin{array}{c}\text { LR and LL areas } \\
\text { similiarites }\end{array}$ & 340 & $34.0 \%$ & 233 & $36.4 \%$ & 107 & $29.7 \%$ & $0.032 *$ \\
\hline $\begin{array}{c}\text { UM and LM areas } \\
\text { similiarites }\end{array}$ & 306 & $30.6 \%$ & 198 & $30.9 \%$ & 108 & $30.0 \%$ & 0.757 \\
\hline
\end{tabular}

$*$ P. value significant $\leq 0.05$

Frequency of different groove types in the different lip areas among the studied population were illustrated in table (2) which revealed that groove type A (complete vertical) was the highest recorded pattern in both males and females $(47.9 \%$ \& $49.7 \%)$ respectively. It was predominantly observed in the lower middle area, Followed by groove type C (complete bifurcation) which represented 43.8 (UL) area in male \& $45.4 \%$ (LR) area in female. While groove type $G$
(Reticular type) represented $(27.0 \%$ \& $24.4 \%$ ) in (UM) area in both males and females respectively. This was followed by groove type E (complete branched) which Constituted $25.0 \%$ (LL) area in males \& $16.9 \%$ (LM) area in females. Groove type D (incomplete bifurcated) represented $15.3 \%$ (UR) area in males \& $19.5 \%$ (UL) area in females followed by groove type B (incomplete vertical) constituted(13.0\% $\& 13.6 \%$ ) in (UR) areas in males \& females respectively.

Table (2): Percent of lip -groove pattern in different lip areas.

\begin{tabular}{|c|c|c|c|c|c|c|c|c|c|c|c|}
\hline \multirow[t]{2}{*}{ Area } & \multirow[t]{2}{*}{ Sex } & \multicolumn{10}{|c|}{ Frequency of lip-groove $\%$} \\
\hline & & $\mathbf{A}$ & $\mathbf{B}$ & $\mathbf{C}$ & $\mathbf{D}$ & $\mathbf{E}$ & $\mathbf{F}$ & $\mathbf{G}$ & $\mathbf{H}$ & $\mathbf{I}$ & $\mathbf{J}$ \\
\hline \multirow{2}{*}{$\begin{array}{l}\text { Upper right } \\
\text { area }\end{array}$} & Male & $16.2 \%$ & $13.0 \%$ & $28.9 \%$ & $15.3 \%$ & $15.3 \%$ & $3.2 \%$ & $3.2 \%$ & $4.0 \%$ & $.0 \%$ & $.9 \%$ \\
\hline & Female & $19.0 \%$ & $13.6 \%$ & $30.8 \%$ & $16.4 \%$ & $11.6 \%$ & $2.0 \%$ & $2.3 \%$ & $4.1 \%$ & $0.2 \%$ & $0.0 \%$ \\
\hline \multirow{2}{*}{$\begin{array}{l}\text { Upper middle } \\
\text { (UM) }\end{array}$} & Male & $38.1 \%$ & $4.7 \%$ & $6.7 \%$ & $2.0 \%$ & $11.6 \%$ & $0.6 \%$ & $27.0 \%$ & $4.9 \%$ & $3.5 \%$ & $0.9 \%$ \\
\hline & Female & $41.7 \%$ & $6.4 \%$ & $8.5 \%$ & $2.0 \%$ & $8.0 \%$ & $0.2 \%$ & $24.4 \%$ & $4.4 \%$ & $3.7 \%$ & $0.8 \%$ \\
\hline \multirow{2}{*}{$\begin{array}{l}\text { Upper left } \\
\text { (UL) }\end{array}$} & Male & $13.3 \%$ & $7.2 \%$ & $43.8 \%$ & $11.0 \%$ & $17.3 \%$ & $2.3 \%$ & $1.4 \%$ & $3.7 \%$ & $0.0 \%$ & $1.0 \%$ \\
\hline & Female & $11.0 \%$ & $9.4 \%$ & $40.6 \%$ & $19.5 \%$ & $12.3 \%$ & $1.5 \%$ & $1.3 \%$ & $4.1 \%$ & $0.3 \%$ & $0.0 \%$ \\
\hline \multirow{2}{*}{$\begin{array}{c}\text { Lower right } \\
\text { (LR) }\end{array}$} & Male & $15.9 \%$ & $10.1 \%$ & $39.5 \%$ & $12.4 \%$ & $15.9 \%$ & $3.7 \%$ & $.6 \%$ & $1.4 \%$ & $0.3 \%$ & $0.3 \%$ \\
\hline & Female & $14.3 \%$ & $8.9 \%$ & $45.4 \%$ & $14.7 \%$ & $10.9 \%$ & $2.3 \%$ & $.8 \%$ & $1.5 \%$ & $0.5 \%$ & $0.8 \%$ \\
\hline \multirow{2}{*}{$\begin{array}{c}\text { Lower middle } \\
\text { (LM) }\end{array}$} & Male & $47.9 \%$ & $5.9 \%$ & $6.8 \%$ & $4.5 \%$ & $18.6 \%$ & $1.4 \%$ & $9.0 \%$ & $3.1 \%$ & $1.4 \%$ & $1.4 \%$ \\
\hline & Female & $49.7 \%$ & $4.9 \%$ & $8.2 \%$ & $2.4 \%$ & $16.9 \%$ & $0.8 \%$ & $10.9 \%$ & $3.0 \%$ & $2.1 \%$ & $1.3 \%$ \\
\hline \multirow{2}{*}{$\begin{array}{l}\text { Lower Left } \\
\text { (LL) }\end{array}$} & Male & $24.4 \%$ & $8.0 \%$ & $25.6 \%$ & $8.3 \%$ & $25.0 \%$ & $3.2 \%$ & $2.3 \%$ & $2.6 \%$ & $0.0 \%$ & $0.6 \%$ \\
\hline & Female & $17.4 \%$ & $8.2 \%$ & $39.0 \%$ & $10.8 \%$ & $16.7 \%$ & $1.9 \%$ & $1.8 \%$ & $2.6 \%$ & $0.5 \%$ & $1.1 \%$ \\
\hline
\end{tabular}

$A=$ complete vertical, $B=$ incomplete vertical, $C=$ complete bifurcated, $D=$ incomplete bifurcated, $\mathrm{E}=$ complete branched, $\mathrm{F}=$ incomplete branched, $\mathrm{G}=$ reticular pattern, $\mathrm{H}=$ $\mathrm{X}$ or comma form, $\mathrm{I}=$ horizontal, $\mathrm{J}$ : others forms 


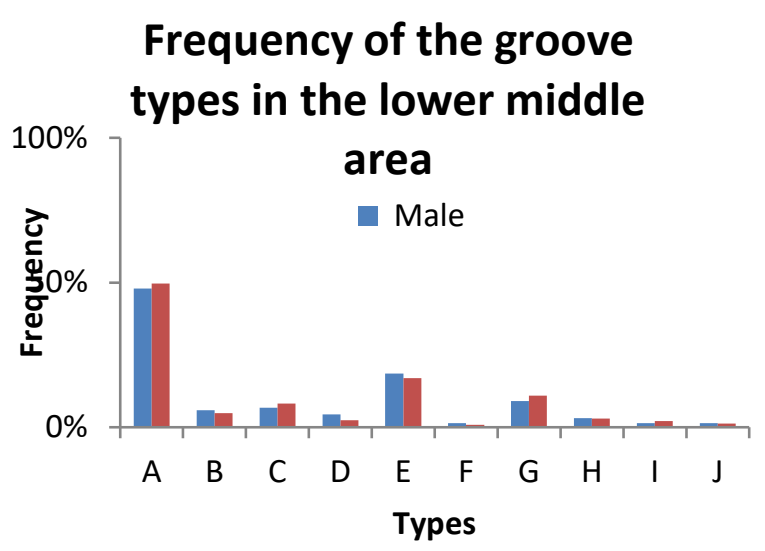

Figure (4): Frequency of groove types in lower middle area in both males and females.

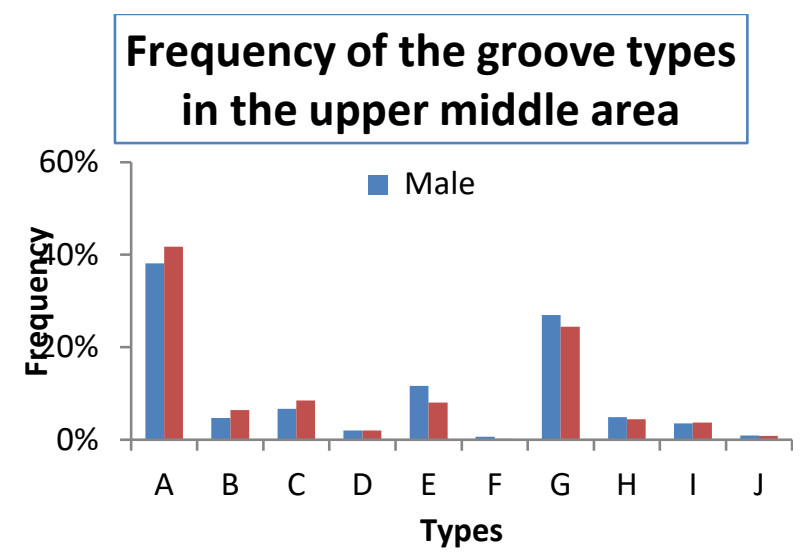

Figure (5): Frequency of groove types in upper middle area in both males and females.

Percent frequency of lip- groove types in lower middle area and upper middle area in both males and female were illustrated in figure $\left(\begin{array}{lll}4 & \& & 5\end{array}\right)$ respectively and showed that type $\mathrm{A}$ (complete vertical) and type E (complete branched) were the highest frequently detected groove types in lower middle area in both sexes. While, type A (complete vertical) and type $G$ (reticular type) were the highest frequently detected groove types in upper middle area in both sexes. Analysis of prints of 34 families showed that lip prints were dissimilar among individuals. Furthermore, study of 15 identical twins showed some similarity in the groove types however, after comparison of the detailed features of their lip prints dissimilarities were recorded.

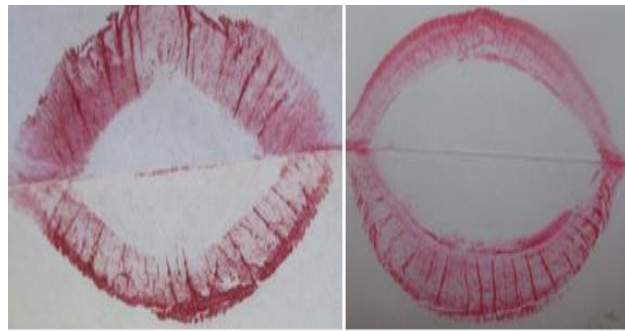

Figure (6): Photographs of lip prints of identical twins showing some similarity in the groove type in the lower lips(vertical type), but the upper lip showed different groove types.

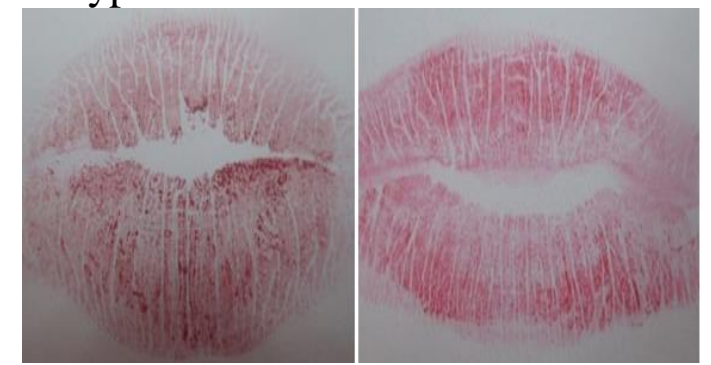

Figure (7): Photographs of lip prints of identical twins showing some similarity in the groove type in the upper lips(complete branched), but the lower lips showed different groove type.

\section{The Following Figures Show} Different Lip -Groove Types.

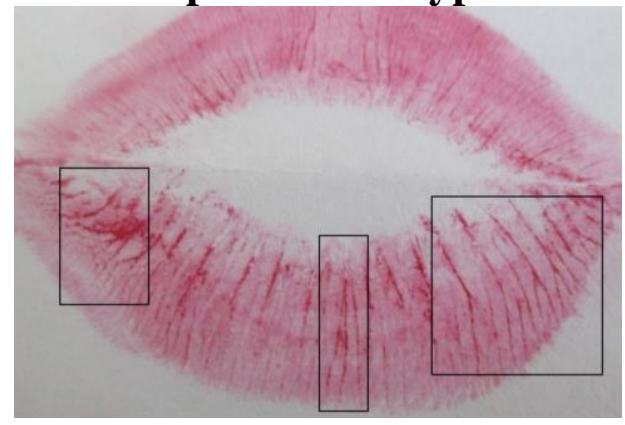

Figure (8): Male lip print showing 3 different lip patterns : complete bifurcated in the LR area,incomplete branched in the LL area,complete branched in the LM area. 


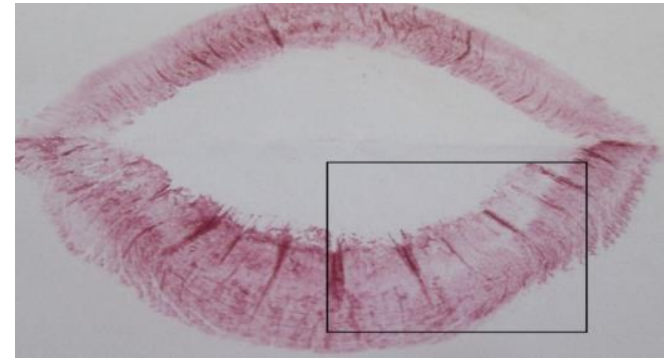

Figure (9): Female lip print showing pattern type $\mathrm{B}$ (incomplete vertical) in LM \&LR areas.

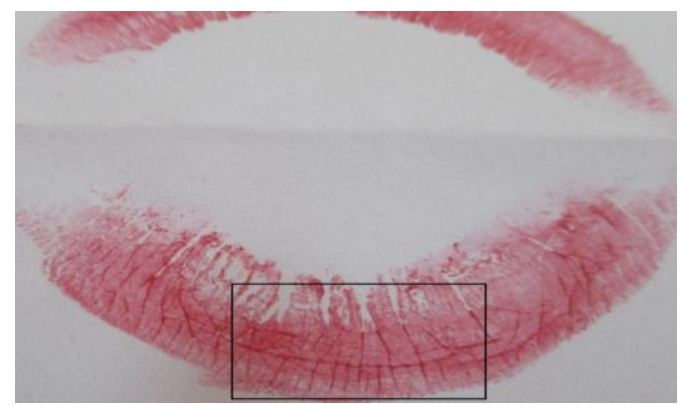

Figure (10): Female lip print showing pattern type J: transverse with other forms in LM area.

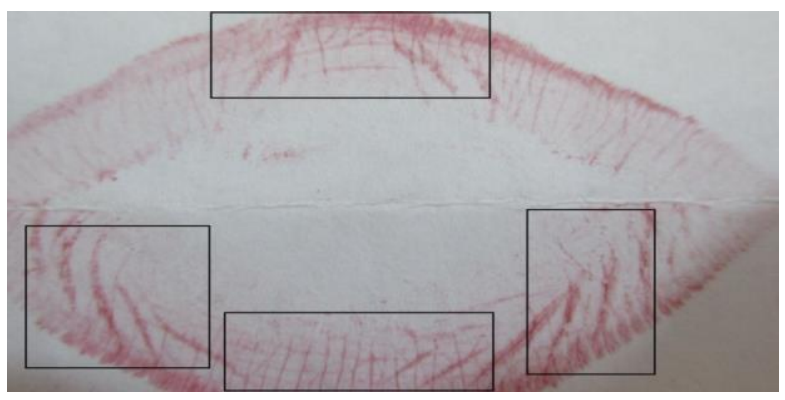

Figure (11): Male lip print showing 2 different lip patterns : reticular pattern in the upper and lower middle areas and other forms in $\mathrm{n}$ the lower left and right areas(curved type).

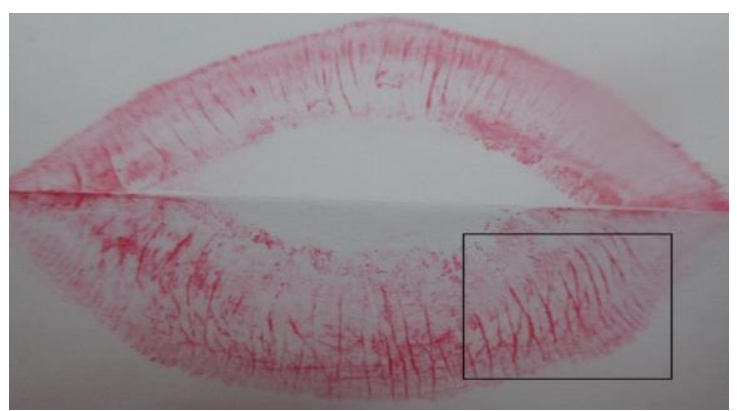

Figure (12): female lip print showing H-type lip pattern(X-shaped) in LR area.

During this study we detected illdefined lip prints in different lip areas as shown in table (3) which denoted that the lower middle area showed the least percent of ill defined lip prints so it is considered the clearest area for lip pattern analysis. In the present study $1.8 \%$ of the prints were not valid for analysis due to smudging of the groove in all areas of the lip.

Table (3): Percentage of ill defined lip prints according to different lip areas

\begin{tabular}{|c|c|c|}
\hline & \multicolumn{2}{|c|}{ ill defined lip prints } \\
\hline Area & Count & \% \\
\hline UR & 44 & $4.4 \%$ \\
\hline UM & 42 & $4.2 \%$ \\
\hline UL & 37 & $3.7 \%$ \\
\hline LR & 36 & $3.6 \%$ \\
\hline LM & 11 & $1.1 \%$ \\
\hline LL & 31 & $3.1 \%$ \\
\hline All areas of the lip & 18 & $1.8 \%$ \\
\hline
\end{tabular}

(UR): upper right (UM): upper middle

(UL): upper left (LR): lower right (LM): lower 
Table (4): Distribution of lip print patterns in relation to different ABO blood groups among the Studied population

\begin{tabular}{|c|c|c|c|c|c|c|c|c|c|c|c|}
\hline \multirow[t]{2}{*}{ Area } & \multirow[t]{2}{*}{ Sex } & \multicolumn{10}{|c|}{ Frequency of lip-groove $\%$} \\
\hline & & $\mathbf{A}$ & B & $\mathbf{C}$ & D & $\mathbf{E}$ & $\mathbf{F}$ & $\mathbf{G}$ & $\mathbf{H}$ & I & $\mathbf{J}$ \\
\hline \multirow{2}{*}{$\begin{array}{l}\text { Upper right } \\
\text { area }\end{array}$} & Male & 16.2 & 13.0 & 28.9 & 15.3 & 15.3 & 3.2 & 3.2 & 4 & 0.0 & 0.9 \\
\hline & Female & 19.0 & 13.6 & 30.8 & 16.4 & 11.6 & 2.0 & 2.3 & 4.1 & 0.2 & 0.0 \\
\hline \multirow{2}{*}{$\begin{array}{l}\text { Upper } \\
\text { middle (UM) }\end{array}$} & Male & 38.1 & 4.7 & 6.7 & 2.0 & 11.6 & 0.6 & 27.0 & 4.9 & 3.5 & 0.9 \\
\hline & Female & 41.7 & 6.4 & 8.5 & 2.0 & 8.0 & 0.2 & 24.4 & 4.4 & 3.7 & 0.8 \\
\hline \multirow{2}{*}{$\begin{array}{l}\text { Upper left } \\
\text { (UL) }\end{array}$} & Male & 13.3 & 7.2 & 43.8 & 11.0 & 17.3 & 2.3 & 1.4 & 3.7 & 0.0 & 1.0 \\
\hline & Female & 11.0 & 9.4 & 40.6 & 19.5 & 12.3 & 1.5 & 1.3 & 4.1 & 0.3 & 0.0 \\
\hline \multirow{2}{*}{$\begin{array}{l}\text { Lower right } \\
\text { (LR) }\end{array}$} & Male & 15.9 & 10.1 & 39.5 & 12.4 & 15.9 & 3.7 & 0.6 & 1.4 & 0.3 & 0.3 \\
\hline & Female & 14.3 & 8.9 & 45.4 & 14.7 & 10.9 & 2.3 & 0.8 & 1.5 & 0.5 & 0.8 \\
\hline \multirow{2}{*}{$\begin{array}{l}\text { Lower } \\
\text { middle (LM) }\end{array}$} & Male & 47.9 & 5.9 & 6.8 & 4.5 & 18.6 & 1.4 & 9.0 & 3.1 & 1.4 & 1.4 \\
\hline & Female & 49.7 & 4.9 & 8.2 & 2.5 & 16.9 & 0.8 & 10.9 & 3.0 & 2.1 & 1.3 \\
\hline \multirow{2}{*}{$\begin{array}{l}\text { Lower Left } \\
\text { (LL) }\end{array}$} & Male & 24.4 & 8.0 & 25.6 & 8.3 & 25.0 & 3.2 & 2.3 & 2.6 & 0.0 & 0.6 \\
\hline & Female & 17.4 & 8.2 & 39.0 & 10.8 & 16.7 & 1.9 & 1.8 & 2.6 & 0.5 & 1.1 \\
\hline
\end{tabular}

$A=$ complete vertical, $B=$ incomplete vertical, $C=$ complete bifurcated, $D=$ incomplete bifurcated, $\mathrm{E}=$ complete branched, $\mathrm{F}=$ incomplete branched, $\mathrm{G}=$ reticular pattern, $\mathrm{H}=$ $\mathrm{X}$ or comma form, $\mathrm{I}=$ horizontal, $\mathrm{J}$ : others forms.

As revealed in table (4), frequency of lip print Type $\mathrm{F}$ (incomplete branched), B(incomplete vertical) and $\mathrm{E}$ (complete branched) were the highest detected patterns among individuals with blood group A positive. While distribution of types I (horizontal) and $\mathrm{H}$ (x-shaped) were the most frequently recorded patterns among individuals with blood group B positive. Moreover, lip print types I (horizontal) and $G$ (reticular) were the most frequently detected patterns among individuals with blood group AB positive. However, lip print type $\mathrm{J}$ (other forms) and $\mathrm{H}$ (x-shaped) showed increased expression among individuals with blood group $\mathrm{O}$ positive.

The correlation was calculated between lip prints and blood groups and also lip prints with gender, both were found insignificant using chisquare test as shown in table (5).

Table (5): Correlation of lip prints with gender and blood groups.

\begin{tabular}{|c|c|c|c|}
\hline Variables & Chi-Square & Degree of freedom & P-value \\
\hline Blood groups & 20.148 & 12 & $0.068^{*}$ \\
\hline Gender & 3.917 & 5 & $0.561^{*}$ \\
\hline
\end{tabular}

*Non significant

\section{DISCUSSION}

Human lip recognition is considered one of the most interesting emerging new tools for human identification, which originates from the criminal and forensic practice as stated by Choras (2009). Studies describing lip prints are rather few despite of their uniqueness and possible prominent help as useful evidence in forensic medicine Uma Maheswari (2005).

This study is the first detailed study carried out at great Cairo to prove the 
individuality of lip print, describing the distribution of 10 known pattern of the prints based on the classification of Renaud (1973) which is considered the most complete classification according to Caldas et al., (2007).

Throughout this study, no subject had single pattern of lip print in all areas of the lip. Our results were in accordance with that reported by Uma Maheswari (2005) who proved the individuality of lip prints in people in Chennai, India and reported that no one had a single groove type in all areas of the lip. On the other hand El Domiaty et al., (2010) stated that few numbers of prints $(9.63 \%)$ had only one type of grooves in all areas of the lip, but two or more types of grooves were commonly seen in different areas of the print during his study among people in Saudi Arabia at Almadinah Almonawarah province.

The present study revealed the presence of some similarities between two different areas of the lip print which were examined and compared. For example $25.2 \%$ of prints showed the same groove pattern in the UR and UL areas. Furthermore, in LR and LL areas $34.0 \%$ of lip prints exhibited the same pattern, $36.4 \%$ of females and $29.7 \%$ of males and this similarity was statistically significant between males and females. In addition the UM and LM areas showed the same lip pattern in $30.6 \%$ of the analyzed lip prints. These results were partially in accordance Gupta et al., (2011) throughout his study on Chinese people who found that the intersected pattern was recorded in compartments 1 and 2 (26\% and $23 \%$ ) respectively, whereas branching type was detected in compartments 3 and 4 (35\% and 32\%) respectively among males. Moreover,
El Domiaty et al. (2010) reported a higher percentage of individuals showing the same pattern in the upper lip and lower lip areas $(72.6 \% \& 75.3 \%)$ respectively.

As regard the distribution of lip groove pattern this study revealed that groove type A (complete vertical) was the most commonly recorded pattern in both males and females $(47.9 \%$ \& $49.7 \%$ respectively. It was predominantly observed in the lower middle area. This was followed by the predominance of type $\mathrm{C}$ (complete bifurcated) in both males and females $(43.8 \% \& 45.4 \%)$ respectively. On the other hand, the least recorded type in both males and females was pattern I (other forms) which was observed in (1.4\% males \& $1.3 \%$ females). This type was not observed at all in the upper left area in males and upper right area in females. In accordance with our findings was Kaur and Garg., (2007) Who proved the predominance of the same groove type in both sexes they found the commonest recorded types were the bifurcate and linear types. In addition, Saraswathi et al., (2009), concluded that the intersecting pattern was the most prevalent type in both males and females (39.5\% and $36.5 \%$ ) respectively. Moreover, these findings were supported by Pradhuman et al., (2011), who found that type II (incomplete vertical) was the dominant pattern in male and female in south India population. This was followed by type III (branched) pattern in both gender $(22.4 \%$ in males and $45.5 \%$ in females). In contrast to the present study Shilpa et al., (2010), have shown that type I (complete vertical 30\%) followed by type II (branched - 36\%) were the most prominent pattern among males while among females type II 
(branched -42\%) was the most prominent type in Mumbai -India. In addition, Youssef \& El. Emary, (1987), found that in Egyptians, the reticular pattern of grooves was the prevalent types in Lower Egypt, while the complete vertical was the prevalent type in Upper Egypt. In contrast to our results Vahanwala \& Parekh (2000), reported that, the predominant type in females differed from that in males and was also not represented in the same area among Indian population.

Researches done on other populations have reported that lip prints had different patterns and distribution that were apparently unique to the individuals. The predominance of the groove pattern differed. For example in Saudi people type $\mathrm{J}$ (horizontal with other forms) and type C (complete bifurcate) were the most prevalent types as reported by El. Domiaty et al., (2010). In Indian population, Sharma et al., (2009) examined the lip print patterns on the middle areas of the lips during their study, and have reported that types I and I' to be the most common among females and type IV among males. Moreover, Vahanwala \& Parekh (2000) conducted a study of lip patterns analysis on 50 male and 50 female and concluded that the $\mathrm{Y}$ shaped and end-to-end patterns are the most frequent. Augustine et al. (2008), investigated 600 individuals and the study showed pattern III to be predominant.

In the present study, analysis of prints of 34 families exhibited different patterns of lip prints among individuals. Furthermore, comparing the lip prints among 15 pairs of twins showed some similarities but after detailed examination lip print pattern were not identical. There are
Conflicting results regarding lip prints analysis in twins. The findings of this study were in accordance with those of Suzuki \& Tsuchihashi, (1970 a), who proved dissimilarities among the studied individuals and suggested that the lip-groove pattern could be influenced by hereditary factors after his study on 107 Japanese families. On the other hand, Suzuki \& Tsuchihashi, $(\mathbf{1 9 7 0} \mathrm{b})$, recorded that there was no hereditary pattern of lip prints and that dissimilarity did not evidently exist between twins. Soon after, Tsuchihashi (1974), examined lip prints of 49 pairs of uniovular Japanese twins and their parents, and recorded that lip prints of twins and their parents were not absolutely identical. However, Uma Maheswari, (2005), stated that no similarities were found between parents and their twins and between twins in Chennaise. Moreover, she added that no similarities were seen between triplets. In addition Shilpa et al. (2010), who stated that after examination of 10 families with twin children there is no significant correlation. Recently, El. Domiaty et al., (2010), after examination of the lip prints of thirteen monozygotic twins in Almadinah Almonawarah province, recorded some similarity in the groove types but the detailed features of lip patterns were not the same.

Correlating lip prints with blood groups may be useful in forensic science for accurate identification of an individual than by using lip prints alone Telagi, et al., (2011). The present study showed that there is no significant correlation between lip prints and blood groups distribution. This could be explained by the presence of different areas or origins of lip prints and blood in intraembryonic 
life Bushra \& Devanand, (2014); however, further studies are needed to elucidate the reason. The results of the current study were similar to those studies done by Shilpa et al., (2010), and Telagi et al., (2011), who concluded that there was no correlation between lip prints and blood groups in south India population. Also our results matched with those recorded by Sandhu et al., (2012), in Punjabi population.

The results of this study revealed no statistically significant correlation between males and females with various lip print distribution that was consistent with the study conducted by Neo et al., (2012) on Malaysian population.

\section{CONCLUSION}

This study confirmed the uniqueness of lip print pattern even in between identical twins and family relatives. That could support cheiloscopy role in identification process, both in civil and criminal issues, On the other hand, the present study disproves any significant statistical correlation of lip print pattern with gender, ABO blood groups. It is recommended to perform more studies on different population groups to analyze the variations and to establish a database to be used as a reference in the criminal investigations together with the provision of the technical and financial support to analyze in depth the correlation between lip prints and ABO blood groups. Similar to efficient machinery (software) for fingerprint detection, a newer cheiloscopy technique has to be developed replacing primitive hand lenses to assess and accurately detect the lip print characteristics.

\section{REFERENCES}

Aggrawal, A. (2004): The Importance of Lip Prints, Mystery Magazine Web, II,, p. 2.

Augustine, J; Barpande, S.R; and Tupkari, J.V. (2008) : Cheiloscopy as an adjunct to forensic identification: A study of 600 individuals. J Forensic Odontostomatol. 26:44-52.

Ball J., (2002): The current status of lip prints and their use for identification. $\mathbf{J} \quad$ Forensic Odontostomatol.; 20: 43-46.

Bushra, K.; Devanand, G., (2014): Cheiloscopy and blood groups: Ai in forensic identification:the Saudi dental journal26,176-180

Caldas, I.M.; Magalhaes, T.; Afonso, A., (2007) : Establishing identity using cheiloscopy and palatoscopy, Forensic Sci. Int. 165 (1) 1-9.

Chan Y.H, (2003): Biostatistics 103: Qualitative Data-Tests of Independence. Singapore Med J.;44(10): 498-503.

Choras, M. (2009): Lip recognition for biometrics. In: Tistarelli $\mathrm{M}$, Nixon MS, editors. Institute of Telecommunications. Berlin Heidelberg: c_Springer-Verlag; pp. 1260-9.

El Domiaty, A.E.; Sami, A.A.; Ahmed, A. E; Maha, D. E.; Sherief A.G.(2010) : Forensic Science International 200: Morphological patterns of lip prints in Saudi Arabia at Almadinah Almonawarah province Forensic Science International 200 (2010) 179.e1-179.9.

Gupta, S.; Gupta, K.; and Gupta O.p. (2011): A study of morphological patterns of lip prints in relation to gender of North Indian population Journal of Oral 
Biology and Craniofacial Research 1 (1)

Kaur, R.; Garg, R.K. (2007): Personal identification from lip prints. Forensic Sci Int.; 169:48.

Kumar, G.S.; Vezhavendhan, N.; Vendhan P.( 2012): A study of lip prints among Pondicherry population.JForensic Dent Sci.;4:84-7.

Molano, M.A.; Gil, J.H.; Jaramillo, J.A.; Estudio, S.M., (2002): queilosco' pico en estudiantes de la facultad de odontologi'a de la Universidad de Antı'oquia, Rev. Fac. Odonto. Univ. Antioquia 14 (1) 26-33.

Neo, X.X; Khairul, O.; Sri, P.A.; Noor, H.H (2012): Lip Prints in Sex and Race Determination. J Sains Kesihatan Malaysia.; 10:2933.

Pradhuman, V.; Suresh, K.S.; Kanika, G. V.; Swati, S. and Kompal S.(2011): Correlation of Lip Prints with Gender, ABO Blood Groups and Intercommissural Distance,J. Forensic Dent Sci.; 3(2): 77-80.

Pradhuman, V.; Suresh, K.S.; Kanika G.V., Swati S., and Kompal S.(2013) : Correlation of Lip Prints with Gender, ABO Blood Groups and Intercommissural Distance, $\mathrm{N}$ Am J Med Sci. Jul; 5(7): 427-431.

Rajendran,

R.; Sivapathasundharam, B. (2009): 6th ed. London: Elsevier, Churchill Livingstone; Shafer's Text book of Oral Pathology; pp. 871-99.

Renaud, M (1973): L'identification che' iloscopique en me' dicine le' gale, Le chirurgien dentiste de France, pp. 65-69.
Renaud, M., (2007): L'identification che' iloscopique en me' dicine le' gale, Le chirurgien dentiste de France, 1973, pp. 65-69.

Sandhu, S.V.; Bansal, H.; Monga, P.and Bhandari R. (2012): Study of lip print pattern in a Punjabi population. J Forensic Dent Sci.;4:24

Saraswathi, T.R.; Gauri, M. and Ranganathan K. (2009): Study of lip prints. J Forensic Dent Sci. 2009; 1:28-31.

Sharma, P.; Saxena, S. and Rathod V. (2009): Cheiloscopy: The study of lip prints in sex identification. $\mathbf{J}$ Forensic Dent Sci.; 1:24

Shilpa, p.; ishbaul, A.S.; Gyathri, R. and SowMya G.V (2010): a study of lip print in relation to gender,family and blood group,int.j.of oral and maxillofacial pathlogy, (1) 1.

Suzuki, K. and Tsuchihashi, Y. (1970 a): Personal identification by means of lip print. J Forensic Med.; 17:52-7.

Suzuki, K. and Tsuchihashi Y. (1970 b): Anew attempt of personal identification by means of lip print, J. Indian Dental Assoc. 42 (1)

Telagi, N.; Mujib, A.; Spoorthi, B.R. and Naik, R. (2011): Cheiloscopy and its patterns in comparison with ABO blood groups. J. Forensic Dent. Sci. 3 (2), 77-80.

Thomas, C.J and Wyk C.W., (1988): The palatal rugae in identification. J Forensic Odontostomatol; 6:21-7.

Tsuchihashi, Y. (1974): Studies on personal identification by means of lip prints, Forensic Sci. 3, 233-248.

Uma Maheswari, T.N. (2005): Lip prints, Master Thesis of Dental 
Surgery Saveetha Dental College and Hospitals, Chennai.

Vahanwala, S.P. and Parekh, D.K. (2000): Study of lip prints as an aid to forensic methodology. J Indian Dent Assoc. 71:269-71.
Youssef, A.T. and El. Emary, A.S. (1987): A study of the patterns of lip prints in Lower Egypt, Proc. First Egypt Int. Cong. Legal Med. 


\section{دراسة الأنماط المورفولوجية لبصمات الثفاه وعلاقتها بالجنس وفصائل الام بين الثعب المصري.}

دينا على شكرى1، نجلاء فريد السيد محمود 1 ، مصطفى محسن مصطفى عفيفي2 1. قسم الطب الثرعي والسموم الإكلينيكية ـ كلية الطب ـ جامعة القاهرة ـ مصر 2. قسم الطب الثرعي والسموم الإكلينيكية ـ كلية الطب ـ جامعة بني سويف ـ مصر الملخص العربي

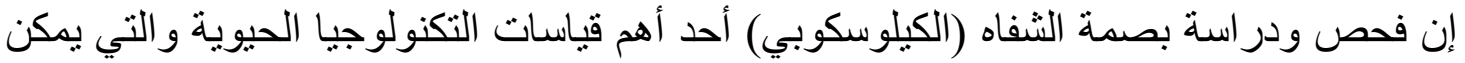

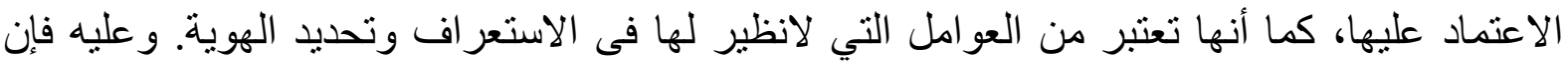

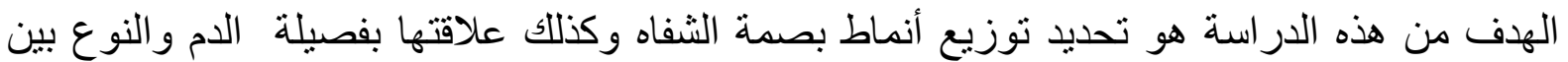

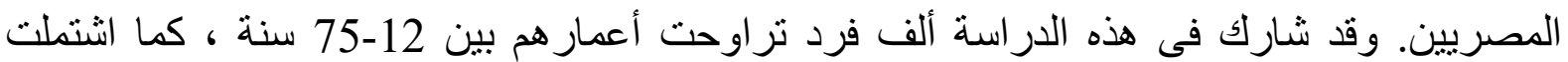

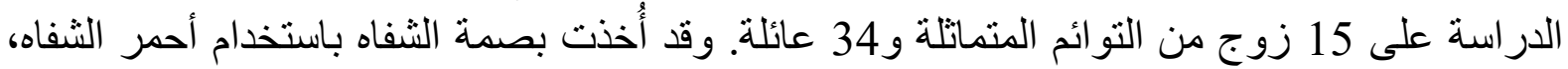

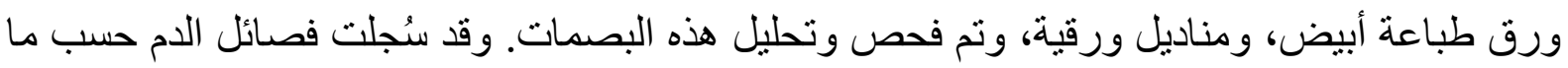

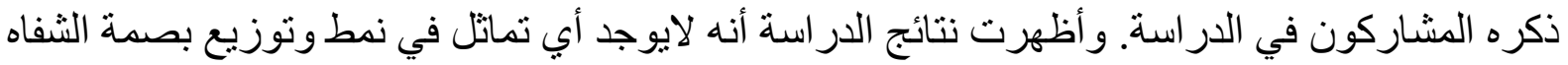

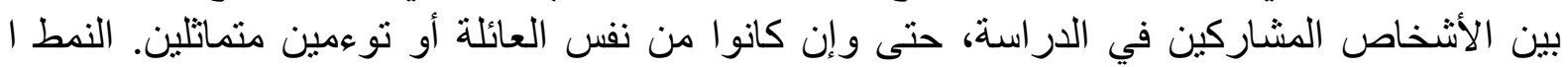

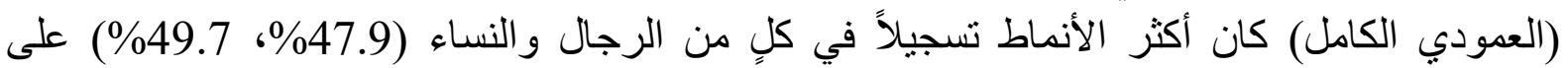

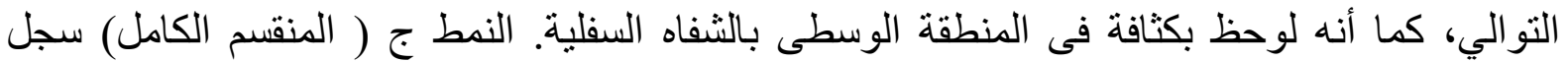

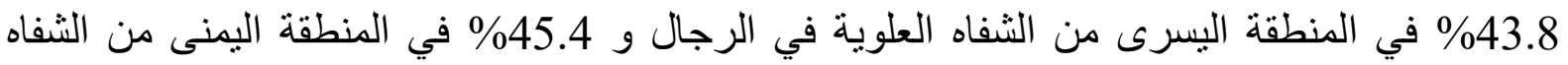

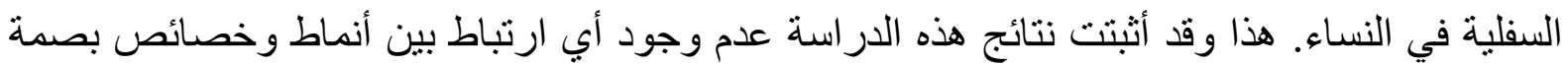

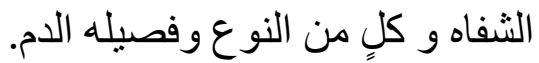

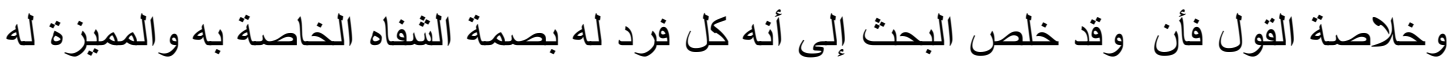

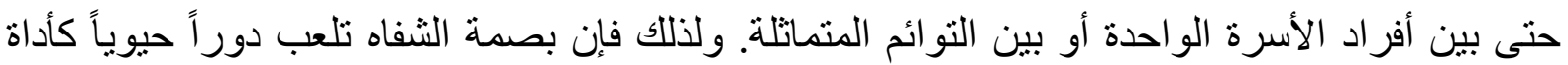
مميزة في الاستعر اف وتحديد الهوية للمشتبه فيهم أو مجهولي الهوية. 